Research Paper

\title{
Non-completed Studies: What Factors Affect Academic Success or Failure?
}

\author{
Edina Kovács ${ }^{1}$ \\ Recommended citation: \\ Kovács, E. (2019). Non-completed Studies: What Factors Affect Academic Success or Failure? Central European \\ Journal of Educational Research, 1 (1), 79 - 89.
}

\begin{abstract}
The ratio of early school leavers is 12.5 in Hungary, which means $22^{\text {nd }}$ place within the EU28. Early school leaving is an important issue in all European countries, because those who finished their studies after primary education are more likely unemployed and it causes problems for both them and the society. Higher educational drop-out also an important issue, although for other reasons than early school leaving. It is even more difficult to find precise data on this: we don't know what proportion of the students is affected by this in Hungary. In this study I analyze the database of the Hungarian Youth Research 2016. This survey was conducted on a representative sample of 15-29 year olds, questioning 8,000 people, therefore, early school leavers and higher educational drop-outs should be found among the interviewees. The results show that early school leavers have significantly worse status both financial and cultural. Some of those who had finished only primary school think that they have successfully completed their studies. They answered that despite 18.3 percent of them have started a vocational training, which didn't finish. Despite the expectations, not much is known about the higher educational drop-outs. 4.5 percent of the interviewees did not answer the question of whether they had completed their studies: they are probably the drop-outs, but we can just assume that. The results show that they have better cultural status than the others.
\end{abstract}

Keywords: early school leaving; high school drop-out; social background; public education

\section{Introduction}

Early school leaving is one of the major issues in the European countries. The European Union intends to reduce the proportion of early school leaving less than 10 percent till 2020. Within the European Union there are more than four million people between the ages of 18 and 24 without qualification and not receiving any formal education. It is a disadvantageous position for a person; young people who do not complete upper secondary education are much more likely unemployed and living in poverty than those who graduated. For the society early school leaving is linked to lower rates of economic growth, higher unemployment, and higher welfare and public health payments. Preventing early school leaving is involves the entire education system as well as policy areas outside of the education system: causes of non-completion are highly complex (Bridgeland et al., 2006; Gitschtaler \& Nairz-Wirth, 2018; Lyche, 2010).

The proportion of early school leavers reduced 10.6 for 2017 in the European Union; in 2012 this number was 12.7. The lowest rate, below 5 percent, is in Croatia, Slovenia and Poland. The highest rate, over 18 percent, is in Malta and Spain. Hungary is $22^{\text {nd }}$, with 12.5 percent. In 2012 this rate was 11.8; while the proportion of early school leavers in the European Union is decreasing, it is increasing in Hungary (Eurostat, 2018).

\footnotetext{
${ }^{1}$ kovacs.edina.12@gmail.com
} 
According to Fehérvári (2015) one of the reasons can be that the situation and attitudes in schools had worsened between 2007 and 2014. There are the most beginner teacher in the most segregated schools, although in these institutions should teach the most experienced teachers with a variety of pedagogical methods. The shortage of teachers in these schools is also the largest, and the teacher shortage increased from 2.1 to 2.7 in this period.

There are different policies in the European Union because there is a significant difference in the severity and magnitude of the issue in the member states. The situation of the post-communist countries was unique for a while because there were transition and structural changes of all sectors (education, economy, welfare state) at the same time (Kogan \& Unt, 2005). Nowadays one of the successful EU member states is Lithuania, where proportion of early school leavers had already fallen to 6.5 in 2012; the ratio was 5 percent in 2017. Lithuania has developed a modular system for vocational training. In the first step they created a modular curriculum; after that the subject-based curriculum was modified according to the new model (Kurucz, 2015).

The model of Lithuania is important, because there is a high rate of drop-out in the first year of vocational training; in Hungary and in the most of European countries. As the good practices show one of the tools of prevention is to strengthen the career guidance services for pupils, during the lower secondary school. Another important tool is the support of transition from lower to upper secondary education (Mihályi, 2015).

Hungarian educational policy had changed in 2011; among other things, compulsory schooling age was turned from 18 years to 16 years. The analyses of KIFIR databases (whose task is to conduct secondary admission processes and to register applications) shows that vocational education is less favorable than secondary school and secondary vocational school, and mostly those pupils choose this way of education who are not motivated to learn and also had poor family background (every second vocational school pupil is a multiple disadvantaged student). These are the students who are more vulnerable and more exposed to early school leaving (Fehérvári \& Híves, 2017).

As we can see above early school leaving is also connected to the early selection. In Hungary (and in many other countries) that is related to family background, which plays a crucial role in the school performance of Hungarian children. As results of Fehérvári (2015) show teachers think that families are responsible for school failures; only few of them see the chance that the school can compensate for those handicaps. And three times more teacher than in 2007 says that the school is not capable of doing so. Teachers' opinions are significantly related to the proportion of Roma students in a given school. Those teachers think that school has no role in the failures who teach in a school with high proportion of Roma students.

Connected to this issue Kende and Szalai (2018) emphasize that the institutional and personal factors hand in hand with the selective competition take Roma students into the lowest-quality segment of vocational training. Due to their disadvantageous situation, the change between schools is often near to their sixteenth birthday when reaching the compulsory schooling age. Because of these reasons educational exclusion and early school leaving affects Roma students more than the majority.

The higher educational drop-out is also an important issue both in the Euro-Atlantic countries and in Hungary; therefore several researches try to investigate the reasons behind. Data shows that 30 percent of students not complete their degree in the USA. About the higher educational students' drop-out ratio no precise data are available in Hungary. The researches examine mostly students' academic performance, because it is an indicator of higher education drop-out. The Hungarian results show that the institutional factors have more significant impact than demographic and social characteristics of students. Students interrupt or delay their studies e.g. because of inappropriately chosen institution and/or course, or employment while studying at a university. So their problems 
are caused by other reasons than the problems of early school leavers in public education (Aulck, 2016; Bocsi et al., 2018; Pusztai, 2018; Tinto, 2006).

\section{Research design and Methods}

This study analyzes the database of the Hungarian Youth Research 2016. The specialty of the research is that since 2000 data are taken up every four years on a large-scale in Hungary. This survey was conducted on a representative sample of 15-29 year olds, questioning 8,000 people. The questions examine the basic indicators and motivations of starting a family, childbirth, education of young people and their plans for further education, their position in the labor market and their leisure habits. Compared to 2012, questions have changed, e.g. about Roma youth. The 2012 survey asked about the Roma ethnic identity, while the 2016 survey about the national identity. The proportion of Roma youth fell back to half in the 2016 sample, although demographic trends do not explain the difference (Bocsi, 2018).

Due to the above, I created a Roma variable. I took into consideration who is a Roma by himself/herself and who the interviewer thinks Roma. This way I can find the other half of Roma people (sum 9.1 percent), as the Table 1 shows.

Table 1. Distribution of responses within the Roma variable

\begin{tabular}{lcc}
\hline & \% & N \\
\hline $\begin{array}{l}\text { Roma by } \\
\text { himself/herself }\end{array}$ & 2.4 & 194 \\
$\begin{array}{l}\text { Roma by both } \\
\text { declaration }\end{array}$ & 1.7 & 135 \\
$\begin{array}{l}\text { Roma by the } \\
\text { interviewer }\end{array}$ & 5.0 & 402 \\
Not Roma & 90.9 & 7270 \\
\hline
\end{tabular}

To measure one's financial situation I also created a variable. I took into account the modern IT and smart devices of a person or a household, so I got a variable between 1 and 10. Other independent variables are the highest level of education of a respondent and his/her parents, the place of permanent address, the language skills and the number of books in a household. The dependent variable is the early school leaving or higher educational drop-out, although it is not easy to define as we will see in the results. During the analysis I used one- and two-dimensional cross table analyses.

During the analysis, I intend to find out how the early school leavers describe. And is there any similarity between early school leavers and higher educational drop-out. My hypotheses are: early school leavers have significantly worse status both financial and cultural than the others. There is significantly higher proportion of Roma between them. I also assume that financial and cultural situation of higher educational drop-out are significantly better, because in their case other factors led to leave college/university without a degree.

\section{Results}

The total number of the sample is 8000 ; the gender ratio is 51.3 percent male $(\mathrm{N}=4105)$ and 48.7 percent female $(\mathrm{N}=3895)$. Groups by age: $15-19$ years 28.8 percent; $20-24$ years: 34.9 percent; 25 29 years: 36.3 percent. There are 2993 people who are still attending school. The other 5007 people are not studying yet. Of these 4386 people say that they are successfully finished their studies. So there should be other 621 people who are early school leavers or higher educational drop-out. This would be almost equal the 12.5 percent, which is the Eurostat data mentioned above (this would 
mean 625 people in this sample), beside of them we should find a few hundred higher educational drop-outs too. But only 7.5 percent (375 people) answered that they not finished their studies.

For another question 19.6 percent (981 people) answered that they were neither working nor studying at that time. More than a half of them are younger than 25 years: 17.1 percent is age 15-19 and 36.9 percent is age 20-24. The gender ratio is 28.3 percent male and 71.7 percent female. 22.6 percent of them completed their studies; not finished 4.9 percent, and 72.4 percent of them did not answer the question.

Almost a half of them (46.4 percent) are at home with their child (Table 2). Less than 15 percent of this group said they had not finished their studies or did not answer the question, so it seems who are in paid childcare at home, mostly are not early school leavers.

Table 2. Situation of non-learning and non-working respondents

\begin{tabular}{lcc}
\hline \multicolumn{1}{c}{ They are now } & \% & N \\
\hline $\begin{array}{l}\text { No job, with } \\
\text { allowance }\end{array}$ & 9.1 & 89 \\
$\begin{array}{l}\text { No job, } \\
\text { without }\end{array}$ & 13.2 & 131 \\
$\begin{array}{l}\text { allowance } \\
\text { Baby care } \\
\text { allowance }\end{array}$ & 4.8 & \\
$\begin{array}{l}\text { Child care } \\
\text { allowance }\end{array}$ & 39.3 & 47 \\
$\begin{array}{l}\text { Full-time mother } \\
\text { Housewife }\end{array}$ & 2.4 & 390 \\
$\begin{array}{l}\text { Dependent } \\
\text { Disability } \\
\text { pension }\end{array}$ & 4.6 & 23 \\
$\begin{array}{l}\text { Social } \\
\text { allowance }\end{array}$ & 16.8 & 45 \\
\hline & 7.5 & 167 \\
\hline
\end{tabular}

As one can see, the proportion of those who are at home with paid childcare is significantly higher with higher graduation level than among those who only finished primary school (Table 3). This may indicate that more people with higher education level have worked before the birth of their child and in their case it is unlikely that having a child has disturbed their studies.

Table 3. Connection between child care allowance and highest level of education (\%)

\begin{tabular}{lccc}
\hline $\begin{array}{l}\text { Highest level } \\
\text { of education }\end{array}$ & $\begin{array}{c}\text { At home with } \\
\text { child care } \\
\text { allowance }\end{array}$ & $\begin{array}{c}\text { At home } \\
\text { without child } \\
\text { care allowance }\end{array}$ & Total \\
\hline $\begin{array}{l}\text { Primary school } \\
\text { Secondary }\end{array}$ & 30.2 & 72.7 & 67.3 \\
$\begin{array}{l}\text { school } \\
\begin{array}{l}\text { College or } \\
\text { university }\end{array}\end{array}$ & 9.8 & 21.8 & 25.4 \\
Total & 100 & 5.5 & 7.3 \\
& \multicolumn{2}{c}{100} & 100 \\
\hline
\end{tabular}

The others don't work for various reasons, but I could not know how many of them did not complete their studies because, as we can see above, there was a very high proportion who did not answer this question. However, their highest level of education turns out from another question, as 
we can see in Table 4. Most of them finished primary school only or had a vocational degree without graduation. So I can assume that some part of early school leavers who didn't answer that question, are among those who took part only primary school education and started to attend some secondary school but had never finished that.

Table 4. Education level of those who are at home without children

\begin{tabular}{lcc}
\hline $\begin{array}{l}\text { Highest level } \\
\text { of education }\end{array}$ & \% & $\mathbf{N}$ \\
\hline $\begin{array}{l}\text { Less than } \\
\text { primary school }\end{array}$ & 3.3 & 32 \\
$\begin{array}{l}\text { Primary school } \\
\text { Secondary }\end{array}$ & 39.7 & 390 \\
$\begin{array}{l}\text { school without } \\
\text { graduation }\end{array}$ & 24.2 & 238 \\
$\begin{array}{l}\text { Secondary } \\
\text { school with }\end{array}$ & 24.4 & 239 \\
graduation & & \\
$\begin{array}{l}\text { College/BA, } \\
\text { BSc }\end{array}$ & 6.9 & 68 \\
University/MA, & 1.5 & 14 \\
MSc & & \\
\hline
\end{tabular}

One other thing characterizes those who currently do neither study nor work. Among them, the proportion of Roma is significantly higher than among those who are still attending school or have a job (Table 5).

Table 5. Proportion of Roma among non-learning and non-working respondents (\%)

\begin{tabular}{|c|c|c|c|}
\hline & Roma & Not Roma & Total \\
\hline $\begin{array}{l}\text { Still attending } \\
\text { school }\end{array}$ & 21.0 & 39.0 & 37.4 \\
\hline Have a job & 41.9 & 51.0 & 50.1 \\
\hline $\begin{array}{l}\text { Neither } \\
\text { learning, nor } \\
\text { working }\end{array}$ & 36.9 & 9.8 & 12.3 \\
\hline No answer & 0.2 & 0.2 & 0.2 \\
\hline
\end{tabular}

As I mentioned above, there was a specific question about successfully finishing studies and 375 people said they had interrupted their studies. Other 247 people did not answer this question. Because of relatively low proportion of school drop-outs, in the following I work with the data of those who are not attending school yet. I consider it appropriate because only 5.3 percent of current students are over 25 years, and two thirds of them are in the 15-19 age group. During the next crosstable analyses I also keep the non-respondents as a separate group: I assume that part of them did not answer because they also had interrupted their studies. The reason behind this statement the lack of school-leavers; we couldn't find them in school-databases of course, but this is a representative sampling so we should see them

The highest level of education is significantly different between groups (Table 6). As we see, the most of the early school leavers have only primary school education level, so they probably fell from vocational training. Among the non-respondent group, the proportion of secondary school graduates is quite high (50.2), so it is possible that some of them are in the high school drop-out category, but 
we can just assume that. 85.4 percent of the non-respondents are working, the rest of them are neither working nor studying.

Table 6. Connection between highest education level and leaving school (\%)

\begin{tabular}{lcccc}
\hline & Primary school & $\begin{array}{c}\text { Vocational } \\
\text { school }\end{array}$ & $\begin{array}{c}\text { Secondary } \\
\text { school }\end{array}$ & $\begin{array}{c}\text { Higher } \\
\text { education }\end{array}$ \\
\hline $\begin{array}{l}\text { Successfully } \\
\text { finished } \\
\text { studies }\end{array}$ & 10.7 & 30.9 & 41.6 & 16.8 \\
$\begin{array}{l}\text { Interrupted } \\
\text { studies } \\
\text { No answer }\end{array}$ & 65.2 & 12.8 & 16.8 & 5.1 \\
\hline
\end{tabular}

${ }^{1} \mathrm{p}=0.000$

The successful academic career strongly depends on the highest educational level of parents. There are significantly more early school leavers from those whose parents have only primary education (Table 7). At the same time, almost everybody who has graduate parents says that they successfully completed their studies. As we see, among the non-respondents' parents relatively high proportion have higher education degree. This may indicate that some of them did not respond because they had interrupted their own higher education studies.

Table 7. Connection between parents' highest education level and leaving school (\%)

\begin{tabular}{|c|c|c|c|c|c|}
\hline $\begin{array}{l}\text { Highest level } \\
\text { of education }\end{array}$ & $\begin{array}{c}\text { Primary } \\
\text { school }\end{array}$ & $\begin{array}{c}\text { Vocational } \\
\text { school }\end{array}$ & $\begin{array}{l}\text { Secondary } \\
\text { school }\end{array}$ & $\begin{array}{c}\text { Higher } \\
\text { education }\end{array}$ & NA \\
\hline & \multicolumn{5}{|c|}{ Mother's education level } \\
\hline $\begin{array}{l}\text { Successfully } \\
\text { finished } \\
\text { studies }\end{array}$ & 21.7 & 31.7 & 35.2 & 8.5 & 2.9 \\
\hline $\begin{array}{l}\text { Interrupted } \\
\text { studies }\end{array}$ & 56.0 & 17.3 & 18.7 & 2.9 & 5.1 \\
\hline \multirow[t]{2}{*}{ No answer } & 14.6 & 28.7 & 36.4 & 14.6 & 5.7 \\
\hline & \multicolumn{5}{|c|}{ Father's education level } \\
\hline $\begin{array}{l}\text { Successfully } \\
\text { finished } \\
\text { studies }\end{array}$ & 18.6 & 43.0 & 25.5 & 8.8 & 4.1 \\
\hline $\begin{array}{l}\text { Interrupted } \\
\text { studies }\end{array}$ & 48.7 & 27.3 & 14.7 & 2.7 & 6.6 \\
\hline No answer & 8.9 & 38.5 & 27.1 & 18.6 & 6.9 \\
\hline
\end{tabular}

There is also a significant difference between the groups in the number of books in their household. In the household of early school leavers have far less book, than in the household of the others, and more than 40 percent of the non-respondents have more than 100 books (Figure 1). There is a similar difference in language skills. Half of those who have successfully completed their studies speak English, less than one third of early school leavers and 70 percent of non-respondents. German is spoken a slightly fewer, but there is also a significant difference between the groups: a quarter of those who have successfully completed their studies, 16 percent of early school leavers and 44 percent of non-respondents speak German. 


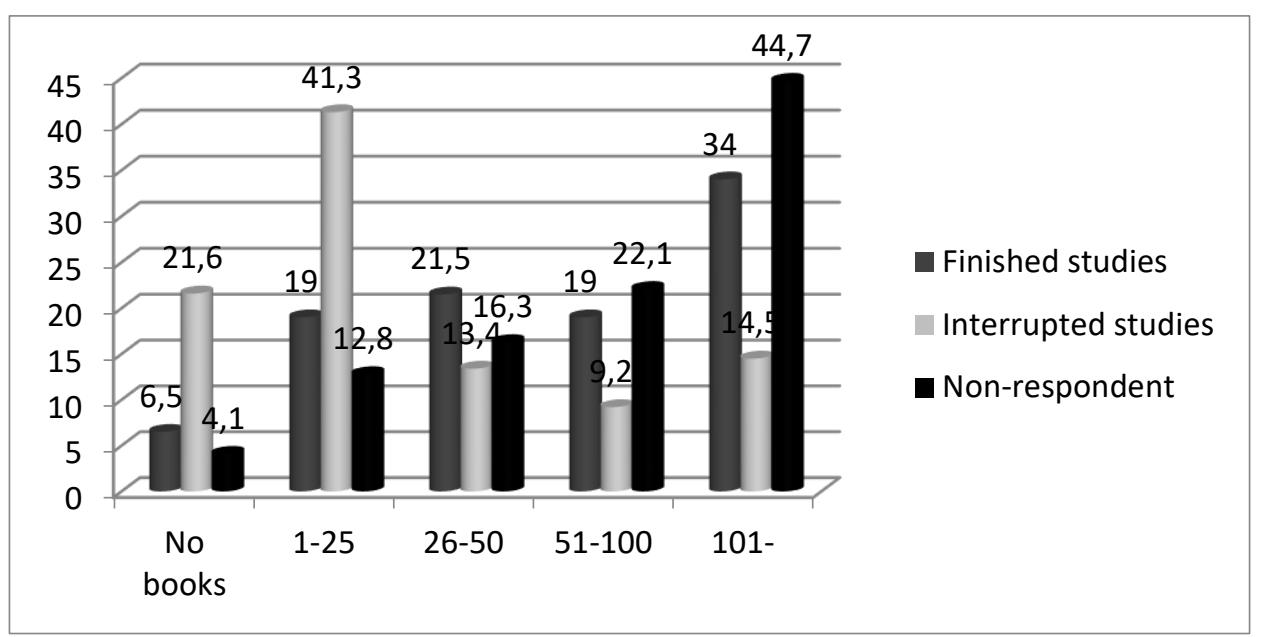

Figure 1. Connection between number of books and leaving school (\%), $\mathrm{p}=0.000$

The variable of the financial situations shows a similar significant difference between these groups (Table 8). The non-respondents have the best financial situation and slightly less favorable for those who successfully completed their studies. Those who left school early have significantly worse financial situation. (Deviation is similar within each category.)

Table 8. Connection between financial situation and leaving school

\begin{tabular}{lcc}
\hline & Mean & Deviation \\
\hline $\begin{array}{l}\text { Successfully } \\
\text { finished } \\
\text { studies }\end{array}$ & 5.79 & 1.96 \\
$\begin{array}{l}\text { Interrupted } \\
\text { studies }\end{array}$ & 4.37 & \\
No answer & 6.27 & 2.31 \\
\hline & 1 sig $=0.000$ & 2.00 \\
\hline
\end{tabular}

The place of permanent address is also significantly different. 80 percent of those who left school early live in a village or a small town, and almost the half of them who didn't answer to the question lives in the capital or a county town (Table 9). The proportion of Roma is significantly higher among early school leavers. More than a third of them Roma while there are only 10 percent Roma in the two other groups.

Table 9. Connection between place of permanent address and leaving school (\%)

\begin{tabular}{|c|c|c|c|c|}
\hline & Capital & County town & Small town & Village \\
\hline $\begin{array}{l}\text { Successfully } \\
\text { finished } \\
\text { studies }\end{array}$ & 15.9 & 19.2 & 32.9 & 32.0 \\
\hline $\begin{array}{l}\text { Interrupted } \\
\text { studies }\end{array}$ & 3.5 & 15.7 & 34.4 & 46.4 \\
\hline No answer & 11.0 & 33.3 & 24.0 & 31.7 \\
\hline
\end{tabular}

Two-thirds of those who had finished only primary school, think that they have successfully completed their studies, although 18.3 percent of them have started a secondary school or vocational training, which didn't finish. The majority of early school leavers (61.8 percent) left vocational training. Among those who got their vocational qualification don't have early school leavers, so they completed their studies and haven't started to learn in any other school. 
90.7 percent of secondary school graduates said they had successfully completed their studies. 2.6 percent said they drop-out and 6.7 percent didn't answer the question. 89.4 percent with higher education degree answered they had completed their studies. 2 percent said they drop-out and 8.6 percent didn't answer the question. That means that some of the higher education drop-out have a degree and interrupted their next major or next level (MA/MSc).

There are significant difference between those who finished their studies and those who didn't that how satisfied they are with certain aspects of their life. The non-respondents and the school dropouts are less satisfied with their spouses, and the early school leavers are the less satisfied with every other thing such as their financial situation, learning and work possibilities. The non-respondents are the most satisfied with their financial situation, learning and work possibilities, so whether or not they are drop-outs, based on their answers most of them found good possibilities (Table 10).

Table 10. Connection between satisfaction with different aspects of life and leaving school (\%)

\begin{tabular}{|c|c|c|c|}
\hline & Not satisfied & $\begin{array}{c}\text { More or less } \\
\text { satisfied }\end{array}$ & Very satisfied \\
\hline & \multicolumn{3}{|c|}{ Relationship with their spouses } \\
\hline $\begin{array}{l}\text { Successfully } \\
\text { finished } \\
\text { studies }\end{array}$ & 9.8 & 13.3 & 76.9 \\
\hline $\begin{array}{l}\text { Interrupted } \\
\text { studies }\end{array}$ & 14.1 & 17.6 & 68.3 \\
\hline No answer & 15.1 & $\begin{array}{c}14.2 \\
\text { Friendship }\end{array}$ & 70.7 \\
\hline $\begin{array}{l}\text { Successfully } \\
\text { finished } \\
\text { studies }\end{array}$ & 3.1 & 11.6 & 85.3 \\
\hline $\begin{array}{l}\text { Interrupted } \\
\text { studies }\end{array}$ & 8.0 & 15.7 & 76.3 \\
\hline No answer & 4.5 & $\begin{array}{c}15.0 \\
\text { Work possibilities }\end{array}$ & 80.5 \\
\hline $\begin{array}{l}\text { Successfully } \\
\text { finished } \\
\text { studies }\end{array}$ & 20.2 & 26.9 & 52.9 \\
\hline $\begin{array}{l}\text { Interrupted } \\
\text { studies }\end{array}$ & 42.1 & 26.4 & 31.5 \\
\hline No answer & 22.7 & $\begin{array}{c}22.7 \\
\text { Financial situation }\end{array}$ & 54.6 \\
\hline $\begin{array}{l}\text { Successfully } \\
\text { finished } \\
\text { studies }\end{array}$ & 22.4 & 37.0 & 40.6 \\
\hline $\begin{array}{l}\text { Interrupted } \\
\text { studies }\end{array}$ & 42.3 & 31.1 & 26.6 \\
\hline No answer & 19.9 & $\begin{array}{c}35.8 \\
\text { Learning possibilities }\end{array}$ & 44.3 \\
\hline $\begin{array}{l}\text { Successfully } \\
\text { finished } \\
\text { studies }\end{array}$ & 18.5 & 27.6 & 53.9 \\
\hline $\begin{array}{l}\text { Interrupted } \\
\text { studies }\end{array}$ & 34.7 & 30.4 & 34.9 \\
\hline No answer & 12.2 & 17.9 & 69.9 \\
\hline
\end{tabular}


If we examine only those whose highest education level is primary school, we see significant differences only in two aspects. Those who think that they have successfully completed their studies at the end of primary school are somewhat less satisfied with their financial situation than those who consider themselves to be early school leavers (Table 11).

Table 11. Connection between satisfaction with financial situation and leaving school (\%)

\begin{tabular}{lccc}
\hline & Not satisfied & $\begin{array}{c}\text { More or less } \\
\text { satisfied }\end{array}$ & Very satisfied \\
\hline $\begin{array}{l}\text { Successfully } \\
\text { finished } \\
\text { studies }\end{array}$ & 58.8 & 22.6 & 18.6 \\
$\begin{array}{l}\text { Interrupted } \\
\text { studies }\end{array}$ & 52.1 & 27.0 & 20.9 \\
No answer & 34.6 & 23.1 & 42.3 \\
\hline & & & \\
& & & \\
& & &
\end{tabular}

Almost the half of those who has only primary school education is dissatisfied with their learning possibilities. Those who consider themselves to be early school leavers are less satisfied than the others (Table 12), this may indicate that they were looking for a learning opportunity which could not be found.

Table 12. Connection between satisfaction with learning possibilities and leaving school (\%)

\begin{tabular}{lccc}
\hline & Not satisfied & $\begin{array}{c}\text { More or less } \\
\text { satisfied }\end{array}$ & Very satisfied \\
\hline $\begin{array}{l}\text { Successfully } \\
\text { finished } \\
\text { studies }\end{array}$ & 46.8 & 23.4 & 29.8 \\
$\begin{array}{l}\text { Interrupted } \\
\text { studies }\end{array}$ & 45.1 & 29.1 & 25.8 \\
No answer & 42.4 & 3.8 & 53.8 \\
\hline & & & \\
& & & \\
\end{tabular}

\section{Discussion}

The results show that early school leavers have significantly worse status both financial and cultural. Their parents have lower education degree, they have less books and their financial status are significantly worse than the others. There is significantly higher proportion of Roma between them. Similarly to previous researches, these results confirm that one's social situation very strongly determines success or failure in school. The majority of early school leavers dropped out from vocational schools. It is noteworthy that two-thirds of those who had finished only primary school think that they have successfully completed their studies. They answered that despite 18.3 percent of them have started a vocational training, which didn't finish. This indicates that they are likely give up studying, which might confirm that they are more satisfied with their learning opportunities.

I assumed that financial and cultural situation of higher educational drop-out students are significantly better, because in their case other factors led to leave college/university without a degree. I can neither reject nor justify it because, based on these data, I cannot be sure who is higher educational drop-out. As I mentioned above, there are no precise data are available in Hungary about higher educational drop-out ratio, and one cannot find out the ratio from this research either. There is only 2.6 percent of secondary school graduates consider themselves as drop-out students which, knowing the international trends is certainly just a small part of the drop-outs. The rest of the dropouts are certainly among the non-respondents. Non-respondents are also characterized by better 
cultural and financial status compared to the others and they are more satisfied with their quality of life. So if the drop-outs are among them, they have a much better social status than early school leavers.

There are limitations of the research, of course. Researching early school leaving or higher educational drop-out is always difficult because the leavers are no longer available in schools, or in the databases, and therefore difficult to reach them. This study based on a large scale national database, for this one can expect that school leavers appear among the others. But only half as many said they had not completed their studies as many are in official statistics. Or less than a half if we count on the fact that someone who has graduated in secondary school, probably had fallen out of higher education. So they are in this sample, but don't want to admit to leaving school. Therefore more than a half of early school leavers do not yet know who they are, but the data still can be useful for the further researches.

Another problematic point is who Roma is in this sample. As I write at the beginning of this study one can be sure that the proportion of Roma youth has not decreased by half. As we all know Roma identity is largely dependent on who is constructing identity. In many cases, it may be a disadvantage if someone declares himself/herself as Roma, so the identity of those who are in a worse position tends to be weaker (Keresztes-Takács, 2017; Walsh \& Krieg, 2007). It is possible that someone who has been declared Roma by the interviewer actually may not be Roma. Yet, since one usually identifies someone as a Roma on the basis of visible marks, I believe that using the variable I have created, I get more accurate results.

\section{Conclusions}

Although only a part of the school leavers have announced that they have interrupted their studies, many of the early school leavers we can find among those who have completed only primary school, but declared that they have completed their learning. This could also mean that those who consider themselves as school leavers with the same qualifications could still be involved in some kind of training. They are those who should probably be paid more attention to reducing the rate of early school leavers. The results also confirm that special attention should be paid to Roma pupils because they are more exposed to the risk of early school leaving.

It can also be seen that higher educational drop-outs are more difficult to find and examine than early school leavers. They might be more ashamed of not completed their studies or being unsure of their own status and therefore not responding the question about their studies. If we want to know more about them in the future, then another researches will be needed and probably with different methods.

\section{References}

1. Aulck, L., Velagapudi, N., Blumenstock, J. \& West, J. (2016). Predicting Student Dropout in Higher Education. CoRR,abs/16606.06364.

2. Bocsi, V. (2018). (Kárpát-medencei) Erőforrástérkép - magyar fiatalok az oktatás világában. In Székely, L. (Eds.), Magyar fiatalok a Kárpát-medencében. Magyar Ifjúság Kutatás 2016. Budapest: Kutatópont Kft. 183-206.

3. Bocsi, V., Ceglédi, T., Kocsis, Zs., Kovács, K., Kovács, K., Müller, A., Pallay, K., Szabó, B. É., Szigeti F. \& Tóth, D. A. (2018). The discovery of the possible reasons for delayed graduation and dropout in the light of a qualitative research study. Journal of Adult Learning, Knowledge and Innovation, https://doi.org/10.1556/2059.02.2018.08

4. Bridgeland, J. M., Dilulio, J. J. \& Morison, K. B. (2006). The Silent Epidemic: Perspectives of High School Dropouts. Washington: Civic Enterprises, LLC.

5. Fehérvári, A. (2015). A hátrányos helyzetú tanulók oktatásának változása, 2006 - 2014. In Fehérvári, A. \& Tomasz, G. (Eds.): Kudarcok és megoldások. Iskolai hátrányok, lemorzsolódás, problémakezelés. Budapest: Oktatáskutató és Fejlesztő Intézet. 31-52. 
6. Fehérvári, A. \& Híves, T. (2017). Trajectories in Hungarian Education - Transition to Secondary School, The New Educational Review, DOI: 10.15804/tner.2017.48.2.12

7. Gitschthaler, M. \& Nairz-Wirth, E. (2018): The individual and economic costs of early school leaving. In: Van Praag, L., Nouwen, W., Van Caudenberg, R., Clycq, N. \& Timmerman, C. (Eds.). Comparative Perspectives on Early School Leaving in the European Union. London: Routledge. 59-73.

8. Kende, Á. \& Szalai, J. (2018). Pathways to early school leaving in Hungary Ethnicised inequalities in education and the case of Roma youth. In: Van Praag, L., Nouwen, W., Van Caudenberg, R., Clycq, N. \& Timmerman, C. (Eds.), Comparative Perspectives on Early School Leaving in the European Union. London: Routledge. 31-44.

9. Keresztes-Takács, O. (2017). Roma fiatalok etnikai identitása és önértékelése egy kérdőíves kutatás tükrében. Esély, 3, 56-72.

10. Kogan, I. \& Unt, M. (2005). Transition from school to work in transition economics, European Societies, 7(2), 219-253.

11. Kurucz, O. (2015). Litvánia. In: Fehérvári, A. \& Tomasz, G. (Eds.), Kudarcok és megoldások. Iskolai hátrányok, lemorzsolódás, problémakezelés. Budapest: Oktatáskutató és Fejlesztő Intézet. 187-201.

12. Lyche, C. S. (2010). Taking on the Completion Challenge: A Literature Review on Policies to Prevent Dropout and Early School Leaving, OECD Education Working Papers, No. 53, OECD Publishing. http://dx.doi.org/10.1787/5km4m2t59cmr-en

13. Mihályi, K. (2015). Az országtanulmányok legfőbb tanulságai. In Fehérvári, A. \& Tomasz, G. (Eds.), Kudarcok és megoldások. Iskolai hátrányok, lemorzsolódás, problémakezelés. Budapest: Oktatáskutató és Fejlesztő Intézet. 230-249.

14. Pusztai, G. (2018). The role of intergenerational social capital in diminishing student attrition. Journal of Adult Learning, Knowledge and Innovation. https://doi.org/10.1556/2059.02.2018.04

15. Tinto, V. (2006). Research and practice of student retention: what next? Journal of College Student Retention. Research, Theory E Practice, 8(1), 1-19.

16. Walsh, C. \& Krieg, B. (2007). Roma Identity: Contrasting Constructions. Canadian Ethnic Studies, 39(1-2), 169-186.

Statictics:

17. Eurostat (2018). Early leavers from education and training. ec.europa.eu/Eurostat 